\title{
On the Question of Ethics Evaluation in the Digital Economy
}

\author{
Jadranskii D.N.* \\ Department of Labor Economics and Personnel \\ Management, \\ Ural State Economic University, \\ Yekaterinburg, Russia \\ e-mail: jadransky@yandex.ru
}

\author{
Chumak E.V. \\ Department of Management and Entrepreneurship \\ Ural State Economic University, \\ Yekaterinburg, Russia \\ e-mail: lena22021977@ yandex.ru
}

\author{
Gurganyan Sh.A. \\ Department of Labor Economics and Personnel Management, \\ Ural State Economic University, \\ Yekaterinburg, Russia \\ e-mail: jadransky@yandex.ru
}

\begin{abstract}
This article focuses on the assessment of moral imperatives and ethics in a digital economy. The main goal of the article is to develop recommendations for authors aimed at creating the prerequisites for assessing the ethics of social practices in the digital economy. The main problem of the article is the lack of a unified methodological paradigm describing social practices in the digital economy. The main research methods were general scientific and special methods, in particular dialectic, systemic, comparative analysis, as well as the method of logical modeling in the development of authors recommendations. The article considers the problem of assessing the ethics of social practices in a digital economy based on the methodological approaches of structural functionalism and postmodernism. A number of scientific and practical problems associated with the assessment of ethics from various methodological positions are identified. Based on the results of the analysis, it is concluded that the main problem of the consumption of an information product that is quite common in the digital economy is extremely problematic to determine whether its consumption is a form of social practice (activity). The problem of the persistence of moral imperatives in postmodern conditions is also considered, which is a problem for conducting an assessment. The concept is formulated, according to which, to assess the ethics of social practices, it is necessary to evaluate not only consumer behavior itself, but also to establish the subjects of its initiators. Insists on the importance of such an assessment and the establishment of clear criteria for such an assessment. It is noted that the attempts of some authors to consider a society using the digital economy as classless are premature. Consumption and its forms, according to the authors, are a product of the social hierarchy, and attempts to get away from establishing the subject of influence and its role in the formation of certain consumption practices are an instrument of social manipulation. The main directions of further research should be scientific research in improving the methodology of structural functionalism in describing the practice of individuals in the digital economy.
\end{abstract}

Keywords - ethics, morality, digital economy, social structure, social practices, postmodern.

\section{INTRODUCTION}

Raising the problems of ethics and moral imperatives in the digital economy, it is fundamentally necessary to determine the paradigm from which this problem will be considered. The most important for analysis is also the social structure within which the indicated morality is evaluated. It should be noted that Russian authors R. Nuriev and O. Karapaev note that at the beginning of the XXI century approximately 15-20\% of humanity begins to live in a post-industrial society, 60-70\% remain in an industrial society, and another 15-20\% may not even go through primary industrialization [1]. Upon that, the authors primarily reduce the information society to the population coverage of digital content.

Without entering into a discussion with the stated point of view, in our opinion, the main scientific problem of ethical assessment is not the coverage of information content as such, but the choice of a basic theoretical paradigm for understanding this problem. Namely, the search for a unified methodological paradigm that describes social practices in the digital economy is the main goal of the article

\section{METHODS AND MATERIALS}

The main research methods are general scientific methods, in particular dialectic, systemic, comparative analysis.

Speaking from the standpoint of the classics of the concept of the digital economy, we should pay attention to the opinion of D. Bell: “... public life is becoming more complicated, as political requirements and civil rights are multiplying, the speed of social changes and changes in behavior standards shock the older generation. And future orientation erases traditional values and moral principles. Information becomes the main resource, and within organizations - a source of strength. Professionalism turns into a criterion of social status, ..." [2, p. 172]. In this context, we can also cite the statement of J. Galbraith, according to which: the criteria of success 
"become the possession of special knowledge and the ability to cooperate. The bearers of these properties are knowledgeable specialists who are the main subject of the new society and who then become part of the technostructure. The technostructure is an apparatus for combining and analyzing information delivered by many people in order to come to decisions that go beyond the competence of each individual ... "[3, p. 55; 4]. A similar point of view is shared by Raul Katz, who noted that the social structure is a new class of the engineering elite according to R. Katz [5]. The indicated opinions are somewhat archaic for the current discussion because the indicated technostructure, at a minimum, does not set values and does not determine the parameters of social development, but only creates an instrumental basis for such actions and ensures the implementation of a specified (from outside) development model. We believe that in the information society there is a certain social structure that shapes and sets the values and norms that determine the direction of social development. According to A. Petrov, digital transformation leads to professional transformation. The success of the digital transformation policy is determined first of all by the presence of professional personnel; interest and opportunities of the business community; material and financial resources; management system; political will of the country's leadership [6, p. 17-18]. In this definition there is partially an influential entity in the face of entrepreneurs and the country's leadership. In other words, there are people, who are interested in deepening digital transformations. Moreover, the definition of such persons is fundamental, since ethics can be assessed in relation to two points of view: in relation to socially established moral imperatives and in relation to moral (other) imperatives given by these entities.

Some attention should be paid to the thoughts of other classics of the information society, in particular to the thoughts of the Japanese scientist Yoshita Masuda [7]. Y. Masuda believes that the development of the information society leads to an increase in the quality of life so much that it is no longer necessary to talk about the existence of such traditional social evil as poverty and destitution, and the other evil - unemployment - is simply transformed into "secured leisure". As a result of this, the social structure of the information society becomes undifferentiated (homogeneous) in the class respect; therefore, all class antagonisms and social conflicts will pass into oblivion (cited in [8]). In this context, we consider it necessary to pay attention to the thesis of $\mathrm{T}$. Parsons: "The fundamental principle of the organization of life systems is that their structures are differentiated in accordance with the requirements of the external environment" [9, p. 99]. We admit that Y. Masuda did not theorize in the concept of structural functionalism, the rejection of the class structure in social relations should be replaced by a different structure, since non-structural iteration loses sociality. Appealing to T. Parsons, with whom we completely agree, any system of action is analyzed in terms of the following four functional categories, which provide:

1) formation of the main, "governing" or controlling samples of the system;

2) internal integration system;
3) its focus on achieving goals in relation to the environment;

4) its adaptation to the influence of the environment, considered in a broad sense, it means to the physical environment that is not associated with the action.

Within action systems, cultural systems perform the function of maintaining a pattern; social systems - the function of integrating existing elements (individuals or, more precisely, individuals who play roles); personality systems the function of achieving the goal; and a behavioral organism - a function of adaptation ... [9, p. 98-99]. Objecting to the archaic nature of this theory, it should be noted that the modern AGIL personnel management model is based on it: adaptation, goal attainment, integration, and latent pattern maintenance [10]. Based on the results of the analysis of classical works, we did not reveal the interest of researchers in the search for a subject that sets cultural norms in the information economy. Basically, the authors agree on the spontaneity of the emergence of certain practices, norms, values (fashion). In our opinion, such spontaneity can be allowed only by adopting the concept of autonomy (outside sociality) of the individual. However, such an assessment loses its meaning due to the absence of social ethics.

Ukrainian author E. Kalnitsky, having carried out a sufficiently substantial analysis of modern discussions on the convergence of digital technologies, determined that they all follow in the footsteps of two positions: optimistic and pessimistic. The optimistic position (John Naysbit, Bill Gates, Nicholas Negroponte, Alvin Toffler, Kevin Kelly, Howard Reingold, George Gilder and others) highlights the prospects of investment opportunities in the new global electronic market, the expansion and improvement of labor productivity, job opportunities, job quality $[11 ; 12]$. In addition, it analyzes the prospects for small businesses, the formation of independent and decentralized forms of production. In politics - decentralization of power, expanding access to unprecedented amounts of information, improving democratic processes, opportunities for all citizens to participate in the process of making state decisions. In the field of culture wide opportunities for mutual understanding and dialogue. Among the critics of this position (Herbert Irving Schiller, Jan Reinecke, Frank Webster, Kevin Robins, Theodore Rozzak, Mark Deri and others) is manifested the idea of the utopian development of technology, which will lead to crisis phenomena in society and its final collapse [11]. The convergence of information technology in terms of this position will strengthen historical trends in socio-economic imbalance, inequality in political power. At the economic level, this scenario predicts the perpetuation of the capitalist mode of production with the aim of further improving managerial control over production processes [13]. To complete the last thesis, we can cite F. Fukuyama's landmark work "The End of History ...", which, in fact, directly indicates the perpetuation of the current model [14]. At the same time, the subjects in whose interests such conservation occurs are quite obvious. It is difficult to admit that having (as an economic and social resource) access to information channels, these entities refuse to use the existing resource in order to advance their own (subjective) interests. The last 
thesis sets the vector of theorizing regarding the ethical issues of the digital economy.

It should be noted that in addition to the fundamental ones, in the process of digitalization of society (and, accordingly, digital economic practices), a significant number of local ethical problems arise. So I. Shumkova notes ethical risks and challenges, namely:

- problems in personal relationships, for example, communication in social networks or professional ethics in the provision of distance medical services, education;

- the problems of transferring part of professional duties to robots, in the relationship of the patient and the robot nurse;

- the problem of privacy, namely the distortion of moral standards of behavior in connection with the possibility of access to information about the activities of political and social institutions, commercial firms;

- the risk of interference with privacy, a tracking and control system for the purpose of commercial or political manipulation of individuals or groups of people;

- problem of the failure of computer systems out of control. [15, p. 3-4]

However, all the above ethical problems can be considered correctly within the framework of classical sociophilosophical concepts. Moreover, from the point of view of the concept of postmodernism, ethical problems lose practically their semantic content. Appealing to one of the postmodern theorists, Jacques Lacan, who "in his initial ethical assumptions was closest to Spinoza ...: good for him is only that, what is good and desirable for person. ... Lacan declares that "the only thing you can be guilty of is to go against your own will." [16, p. 104]. Integrating this concept with the opinion of Y. Masouda about the social structure of the information society that is not differentiated (homogeneous) in the class relation, it can be stated that ethics is replaced by desire. At the same time, the fundamental question remains open: the source of such a desire. Spinoza determines "something like an imperative of authentic behavior - not to stiffen in the once chosen way of existence (that would be just equivalent to "be" as an unauthentic way of being), not to identify oneself with one's deeds, actions ("a person is free from his past") and creations (none of the genius is confined to their works), but to overreach oneself constantly, to go beyond own limits, and to transcend (cited from [16, p. 103-110]). Cultural norms that ensure the translation of moral imperatives and, accordingly, the criteria for moral evaluation become "free from the past" and acquire a situational (momentary) character. At the same time, the need for such an assessment for society does not lose its significance, provided that society is considered in the classical sense (as a social structure).

In fact, postmodern evinces postmodern postulates through the means of modern information, namely the concepts of Lacan and Spinoza create the prerequisites for the construction of modern information practices. By imposing the AGIL methods: adaptation, goal attainment, integration and latent pattern maintenance, each socio-economic subject "reconstructs himself". Under these conditions, the concepts of culture and other social restrictions are removed and, accordingly, the destruction of classical ethics occurs. More precisely, its transformation is taking place within the framework of the paradigm of freedom from the "self of the past." Developing the concept of postmodern ethics in Lacan's worldview, I. Kudryashov notes: "The form of expressing private desire can be accepted as a universal law, passion can be ethical, and, on the contrary, performance of duty is not proof of the morality of the act" [16, p. 105]. In our opinion, it is fundamentally important to answer another question regarding the driving forces of the economy in postmodern society. As one of the postmodern theorists J. Baudrillard noted, a certain intellectual infertility arises from the postmodern, called by Jean Baudrillard"the realm of complete freedom - total not-affection for-anything, not-responsibility for-anyone, not-belief in-anything» [17, p. 52]. Attention should be paid to the absolutely fair opinion of $M$. Rumyantsev, who notes that "Post-industrialism is not developing, but is simulated. The main products of the new economy, as a rule, are marketing, financial and humanitarian schemes for selling products of the industrial economy" $[18$, p. 173]. In the last definition, the main driving forces of the postmodern economy are hidden - the lack of a real artifact and information as the main product.

The physicist Michael H. Goldhaber approximates to the solution of this problem more deeply. The researcher notes: "My main idea was that the real goal in the situation of choosing information is attention - the attention of other people. The scope of such attention is limited, since each person can give only own attention throughout life. At the same time, attention is undoubtedly desired; it is necessary for everyone, and unlike wealth, there is not too much attention. Therefore, both existing and future "information technologies" are better understood as "attention technologies", each of which offers its own specific path of attention-seeking [19].

It should be noted one more thought of M. Rumyantsev that the Postmodern paradigm does not go beyond the liberal positivistic attitude towards the Modern era, it only extremely subjectivizes and psychologizes this attitude [20, p. 166]. Developing this it can be stated that the subjectivization of the worldview leads to the differentiation of ethics, giving it a changeable, situational character. At the same time, Yu. Habermas in his work "The Future of Human Nature", exploring the ethical aspects of the latest technologies, raises the question: how should we understand ourselves, who we are and who we want to be? $[21$, p. 3]. The answers to these questions, according to Yu. Habermas, center around moral beliefs that limit freedom effectively only if they are rooted in ethical self-awareness, combine the care of their own welfare with an interest in justice.

\section{CONCLUSION}

Thus, summing up the theorization, it becomes possible to identify two main problems of ethics in the information economy: 
- the problem of scientific theorizing - due to the application of various paradigms to describe the information economy;

- the problem of the persistence of the existence of moral (cultural) imperatives in a postmodern society.

In practice, from these problems follows the problem of subjectivity of influence. In other words, the disclosure of the mechanism for the formation of a specific desire by an individual. The purpose of the formed desire is to stimulate his/her action in the postmodern economy (attracting attention). At the same time, the question remains whether the consumption (production) of information product in postmodern society is a social action. In our opinion, any act of consumption can be considered as a social action, but not always, such an action can be identified as actually social in the current period. Especially based on the fact that the immediate tool for the formation of desire is to attract the attention of an individual (and not the individual as part of society). Since the attention arising from an individual does not necessarily determine the interaction in the current period, because of this, the fact of the occurrence of interest (attracting attention) cannot be unambiguously identified as a social action itself. The lack of sociality in action, in our opinion, fundamentally complicates or makes impossible the assessment of its ethics. Such impossibility, however, exists only within the framework of the concept of postmodernism. Improving the concept of structural functionalism, in our opinion, is a methodological alternative to postmodernism, capable of providing answers to the posed questions. However, to use this concept, it is necessary to rethink the subjectivity of informational influence on value (moral) orientations by controlling the attention of the masses. The last thesis, in our opinion, is the urgent task of scientific theorizing the entire totality of social and humanitarian sciences.

\section{References}

[1] R.M. Nuriev, O.V. Karapaev, "Tri etapa stanovleniya czifrovoj ekonomiki”, J. of econ. regulat. (Voprosy regulirovaniya ekonomiki), vol. 10 , no. 2 , pp. 6-27, 2019.

[2] D. Bell, Gryadushhee postindustrial noe obshhestvo. Opyt soczialnogo prognozirovaniya. Moscow: Academia, 2004, 788 p

[3] K.V. Patyrbaeva, "Sovremennyj soczium, trud i chelovek v konczepcziyakh postindustrial nogo obshhestva", Vest. Permskogo univer. Filos. Psikhol. Socziol., no. 2. 2012, Retrieved from: https://cyberleninka.ru/article/n/sovremennyy-sotsium-trud-i-chelovekv-kontseptsiyah-postindustrialnogo-obschestva (data obrashheniya: 03.01.2020).

[4] Dzh. Gelbrejt, Novoe industrial noe obshhestvo. Moscow: AST; Tranzitkniga; Terra Fantastica, 2004, 602 p.

[5] A.A. Petrov, "Czifrovizacziya ekonomiki: problemy, vyzovy, riski", Torgovaya politika, vol. 3, no. 15, 2018, Retrieved from: https://cyberleninka.ru/article/n/tsifrovizatsiya-ekonomiki-problemyvyzovy-riski (data obrashheniya: 31.12.2019)

[6] R. Nicole, "Title of paper with only first word capitalized", J. Name Stand. Abbrev., in press.

[7] R.L. Katz, The Information Society: An International Perspective, New York: Praeger, 1988, $168 \mathrm{p}$

[8] A.A. Petrov, "Cifrovizaciya ekonomiki: problemy, vyzovy, riski", Torg politika, vol. 3, no. 15, 2018, Retrieved from: https://cyberleninka.ru/article/n/tsifrovizatsiya-ekonomiki-problemyvyzovy-riski (data obrashcheniya: 31.12.2019)

[9] Y. Masuda, The Information Society as Post-Industrial Society, Washington, D.C.: World Future Society, 1981, 171 p.

[10] R.F. Abdeev, Filosofiya informacionnoj civilizacii. Moscow: VLADOS, 1994. $-336 \mathrm{p}$

[11] T. Parsons, Ponyatie obshchestva: komponenty i ih vzaimootnosheniya, Thesis, Vesna 1993, vol. 1, no. 2, Retrieved from: http://ecsocman.hse.ru/data/876/582/1217/2_2_1pars.pdf, p. 99

[12] O.V. Arlashkina, "Koncepciya T. Parsonsa kak instrument teoreticheskogo analiza social'nogo vzaimodejstviya $\mathrm{V}$ sisteme upravleniya kadrami organizacij", Teoriya i praktika obshchestvennogo razvitiya, no. 3, 2010, Retrieved from: https://cyberleninka.ru/article/n/kontseptsiya-t-parsonsa-kak-instrumentteoreticheskogo-analiza-sotsialnogo-vzaimodeystviya-v-sistemeupravleniya-kadrami-organizatsiy (data obrashcheniya: 04.01.2020)

[13] Zh. Bodrijyar, Obshchestvo potrebleniya. Ego mify i struktury. Moscow: Respublika; Kul'turnaya revolyuciya, 2006, 269 p.

[14] E. Toffler, Tret'ya volna, per. s angl. pod red. P.S. Gurevicha. Moskva: AST, 2004, $781 \mathrm{p}$

[15] E.A. Kal'nic'kij, "Konvergenciya yak klyuchovatendenciyarozvitku cifrovogo suspil'stva", Visnik HNU imeni V.N. Karazina, no. 1116, Ser. Filosofiya. Filosofs'kiperipetiï, 2014

[16] D.N. Yadranskij, "Akademicheskij banditizm: avtorskij vzglyad", Diskussiya, vol. 1 no. 86, pp. 6-13, yanvar' 2018.

[17] I.Yu. Shun'kova, "Social'no-eticheskie aspekty cifrovoj ekonomiki", Sovremennaya antimonopol'naya politika Rossii: pravoprimenitel'naya praktika v Bryanskoj oblasti, pp. 220-223, 2019 [Vserossijskaj nauchno prakticheskaj konferencij]. Bryansk.

[18] I.S. Kudryashov, "K voprosu o klassifikaciyah eticheskih koncepcij (na primere problemy klassificirovaniya etiki psihoanaliza Zhaka Lakana)", Vest. Novosibirskogo gosudarstvennogo univer.. Ser. Filosofiya, vol. 8 , no. 2, pp. 103-110, 2010.

[19] Zh. Bodrijyar, Simvolicheskijobmen i smert'. Moscow: Dobrosvet, 2000, $389 \mathrm{p}$

[20] M.A. Rumyancev, "Ekonomika obshchestva Postmoderna: kriticheskij analiz", Hristianskoe chtenie, no. 6, 2012, Retrieved from: https://cyberleninka.ru/article/n/ekonomika-obschestva-postmodernakriticheskiy-analiz (data obrashcheniya: 31.12 .2019 )

[21] M.H. Goldhaber, "My recent interview by Bitsy Knox", Eyequant, Retrieved from: https://goldhaber.org/my-recent-interview-by-bitsyknox-eyequant/

[22] M.A. Rumyancev, "Ekonomika obshchestva Postmoderna: kriticheskij analiz", Hristianskoe chtenie, no. 6, 2012, Retrieved from https://cyberleninka.ru/article/n/ekonomika-obschestva-postmodernakriticheskiy-analiz (data obrashcheniya: 31.12.2019)

[23] Yu. Habermas, Budushchee chelovecheskoj prirody. Moscow: Ves' Mir, $2002,144 \mathrm{p}$ 